\title{
Selling Across the Spectrum: The Multiplatform Brand Flows of Heroes
}

\author{
ERIN GIANNINI, independent scholar
}

\begin{abstract}
This article examines how the NBC show Heroes and its use of product placement across multiple platforms represented an early response by networks and advertisers to concerns over ad-skipping and alternate viewing platforms by attempting to reconfigure how brand flow operates across multiple platforms. Not only did the series employ 'second shift aesthetics' (Caldwell 2003, 135), which represents networks bringing viewer-users back to the programme by 'further engag[ing] and activat[ing] the text' (Caldwell 2004, 50), but the products integrated within the text are pulled into the available world of Heroes' alternative platform's textual world, particularly Nissan branded cars. As Henry Jenkins writes: 'Old media are not being displaced. Rather, their framework and structure shifted by the introduction of new technology' (2006, 3-4). How these products are used within Heroes storylines and its interaction with characters and platform goes beyond simple placement to make the product another character within the show.
\end{abstract}

Further, I examine the way in which Heroes, as a transmedia text, provided many points of entry for viewer-users to interact with it. While an analysis of fan activity is not the focus of this article, it is important to note these possibilities because of the ways in which the promotional apparatus of the network utilized these types of convergences for the series. Yet, in the case of Heroes, this was achieved by suturing new technological abilities of brand extension with an older model of adsupported television (namely, the single-sponsorship model of early American television), both within the terrestrial television series and across multiple platforms. With the 2008 writers' strike derailing narrative television for that season-leading to prematurely ended or truncated seasons, or outright cancellations - these transmedia elements became both contentious and useful on both the production and narrative level.

\section{KEYWORDS}

Branding, multiplatform, product placement, transmedia.

\section{Introduction}

Certain television viewers have long chosen to engage with television texts on a more intense level, reconstituting, remixing, or re-envisioning plots, stories, and characters through fan-created fiction, videos, and music (Jenkins 1992; Fiske 2006). NBC's science fiction series Heroes (Tailwind Productions/NBC Universal Television Studio, 2006-10) provided many points of entry for this type of activity, particularly the ways in which it attempts 'transmedia storytelling' (Jenkins 2006, 95). That is, Heroes dispersed plot and characters across multiple platforms, tailoring content to particular media: television, graphic novels, web episodes (webisodes), or interactive games. 
Heroes further represents an example of John T. Caldwell's contention that the networks have responded to the fragmentation of US television by expanding the boundaries of the series brand $(2003,131)$ through these transmedia elements. In the case of Heroes, this extends not just to the text itself, but to the advertising and product placement agreements that supported the series. Heroes employed an older model of ad-supported television (namely, the single-sponsorship model of early American television), both within the terrestrial television series and across multiple platforms, suturing old models with new technology through the use of advanced branding. Paul Grainge asserts that branding is 'linked to key transformations and developments within contemporary culture industries' (Grainge 2007, 8-9), particularly with the increased alternate viewing modes such as digital video recorders and online viewing. As Celia Lury argues that brands serve as 'marks of flow' (Lury 2004, 13) across multiple iterations, Grainge too examines how branding 'has assumed the pose of entertainment' while the entertainment industries have 'increasingly assumed the function and status of a brand' (Grainge 2007, 25). To that end, I will examine how, through both product integration and branding, Heroes works to conflate the product and the character within all potential outlets for the series.

After providing a brief review of the industrial context of the series, including the position of NBC as a network from 2004 to Heroes' debut in 2006, I will provide an analysis of an episode that aired on broadcast television, and one of the webisodes that aired in the summer of 2008. I have chosen to examine one of these webisodes because of the ways in which they position themselves as a part of the text and context of television's commodity form; that is, they are structurally similar to the programme itself both in the quality of video and in the use of product placement. In this way, the webisodes replicate, as Caldwell puts it, the first-shift uses of flow in a second-shift context. That is, digital media offers not so much a break with traditional media or cynical corporate strategy, but rather an example of how the television industry is using said media to 'leverage cultural capital', increase visibility, and provide financial benefit (Caldwell 2003, 131) through the use of both text and advertising across these multiple platforms. Heroes employed interactive storytelling, graphic novels, webisodes, and adjunctive websites related to the series to extend the narrative. A character or plot could be introduced within the terrestrial series, a webisode, or a graphic novel, and transition from one to another, with their narrative arc split between mediums, which had the unfortunate consequence of giving the impression of unresolved or poorly conceived plots or characterization. What did remain consistent however, was the use of product placement across these multiple platforms, addressing the viewer at each point of textual entry as well as seeking to control viewer or fan interaction with the Heroes brand. If, as Adam Arvidsson argues, brands represent 'hypersocializied, deterritorialized factories' (Arvidsson, 2006: 82), than the level of control the NBC network sought over viewer interaction - that is, simultaneously 'inviting them in' and conscripting their activities (Johnson 2007) - takes on a deeper resonance.

\section{From Hero to Zero}

After an unprecedentedly long run as the top network in the 1980s and 1990s, the NBC network struggled to regain its old position at the top after the shows that fueled its rise, such as Friends (Warner Bros./Bright/Kauffman/Crane Productions, 1994-2004) and Frasier (Grub Street Productions/Paramount Television, 1993-2004), were retired. Amanda Lotz has argued that part of NBC's struggles were due to their attempts to recreate their earlier success in the 1980s, which featured family-friendly programming with broad appeal (2007a, 271). In an environment in which media was fragmented and niche oriented, Kevin Sandler also argues that NBC negotiated such changes by increasing their level of reality programming, employing different launching strategies, using on-screen talent for cross-promotion, and - most importantly for the purposes of this analysis 
- increasing promotion across multiple platforms and the level of product integration within their programmes $(2007,293)$. David Baldwin, the executive vice-president of the Showtime network, praised NBC for its multiplatform initiatives, such as its TV $360^{\circ}$ website as well as the joint venture with News Corporation that would eventually become known as streaming service Hulu (Atkinson 2007b). John Wells, on the other hand, claims that high levels of product integration are far more common for networks that are struggling in the ratings (Levin 2006).

Heroes represents an in-house production for NBC Universal and was developed with a focus on how it could be both promoted and told, textually, across multiple platforms. In an interview, the show's creator Tim Kring and producers Damon Lindhoff and Jesse Alexander argue that what during the analog era would have been considered 'soulless [...] cross promotion' is, in the digital era, 'transmedia storytelling' (Kushner 2008). That is, the multiple platforms not only promote a series, but are used to build and expand the world of the series - not just within the television medium, but on numerous official adjunctive websites. NBC offered the Primatech Paper website (the company within the series that serves as a front for experiments on individual heroes); a 'Create Your Hero' contest for mobile phones; and character blogs, wikis, comic books, and a fulllength novel about a subplot between the character of Hiro Nakamura (Masi Oka) and a waitress named Charlie Andrews (Jayma Mays) (Wallington 2008). The majority of this content was funded by sponsors such as Cisco, Nissan, Sprint and Apple. Each sponsorship represents a mutually beneficial contract between content and sponsor: Cisco Systems' sponsorship of the Primatech Paper website, which used a Cisco brand interface to allow viewer-users to spy on the company, allowed Cisco to promote their new line of surveillance cameras. Telecommunications company Sprint sponsored the majority of the mobile phone content, as well as the online episodes (explored in greater depth below). In 2007, NBC posted a $\$ 50$ million profit from this type of online advertising revenue (Kushner 2008).

Thus, Heroes embodies both the initiative and struggles of its network. While the additional revenue stream was appreciated, even a cursory examination of trade journals such as Variety, Advertising Age and Broadcasting and Cable indicates that networks and advertisers spent the majority of the decade reacting and adjusting to new technologies and platforms, such as the digital video recorder, the increased ability and availability of online streaming, and the popularity of the DVD format, particularly for releasing television series. Despite these new revenues, networks and advertisers consistently anticipated that each technology would fundamentally shift the programme/advertiser paradigm, and the billions in profit it generated (see McClellan 2003; Thompson 2004; Donotan 2005; Winslow 2007; Atkinson 2007a and 2007b; Learmonth 2007 and 2008). A series such as Heroes, with its large cast and numerous plots and subplots, represented an opportunity for the network to, in essence, make these multiple platform capabilities an essential part of the narrative of the series. Transmedia storytelling thus became a necessary element of the Heroes brand. As such, these non-broadcast elements offered the same opportunities for product integration as the terrestrial series itself.

\section{Product Placement to the Rescue?}

Nissan represents the most important product relationship within the show. The series premiere was presented with limited commercial interruption, thanks to the single sponsorship of Nissan.

According to Lotz, this follows a trend within both broadcast and cable programmes toward single sponsorship of particular episodes within a series. This sponsorship, she claims, can 'allow for the creation of narratives of some distinction' $(2007 \mathrm{~b}, 174)$ since the story need not be written to the ad 
break. Indeed, single sponsorship has been used for event programming, such as broadcast debuts of what might be considered historically important or sensitive films, such as Schindler's List (its broadcast on 23 February 1997 being sponsored by Ford) or Saving Private Ryan (on Veterans Day from 2001 to 2004). Thus, not only does single sponsorship allow for the uninterrupted storytelling, but carries particular associations with event-status programming.

The distinction Lotz claims such sponsorship can bring is comparable with Derek Kompare's analysis of the tangibility of television through its publication on DVD, which eliminates much of what associates these stories with television - namely, the advertising breaks - and thus positions the show as quality programming by disassociating it from its televisual roots $(2006,349)$. Further, the positioning of Heroes as what Matt Hills calls 'mainstream cult' - that is, series that contain elements of both mainstream television (such as narrative drive, 'high gloss' production, and an ensemble cast) and cult (fantastic premise and a 'detailed hyperdiagetic world about which the cult audience can amass textual knowledge' (Hills 2010,71)) - provides a space in which discourses of quality and those of cult television intersect. Indeed, Roberta Pearson explicitly draws the two together, citing numerous critics and viewers who have marked cult series with the added designation of quality $(2010,7-8)$. It is within these definitions - cult as quality or 'mainstream cult' - that Heroes and its paratexts (Gray 2010) have been positioned. It has explicitly branded itself and its associated products as such across multiple platforms.

As stated earlier, it is arguable that the most important sponsorship relation for their series is with Nissan. For Heroes, Nissan not only served as the single sponsor for the debut, as mentioned above; they also subsidized the distribution of the premiere episode free of charge on iTunes three weeks before it debuted on broadcast, previewed the show in cinemas, and distributed gift cards for Heroes-related iTunes downloads to theatre patrons (Lafayette 2006). In return, the Nissan model Versa was heavily promoted through the first series; in the second season, the model Rogue was also added, specifically for the character of Claire Bennet (Hayden Panettiere), a high school cheerleader with self-healing powers.

It was the character of Hiro Nakamura, however, that represented a vocal and central mouthpiece for Nissan's integration into the world of the show. Nissan is the only make of car featured within the programme, thereby undermining one argument for product placement, that it represents 'verisimilitude' (Avery and Ferraro 2000, 217). While this argument generally indicates that brands exist in the real world and so to not show brands would not be true to a portrayal of the contemporary American world, Nissan is nearly the only car displayed in the Heroes universe, which decidedly does not reflect contemporary reality. Hiro's name itself reflects his connection with the company; Nakamura is the last name of the chief executive officer for Nissan, tying Hiro implicitly to the product. According to Tim Kring, the creator of Heroes, this was done as a show of thanks for Nissan's unstinting support for the show; Nissan's sponsorship is also an in-joke within the cast itself. ${ }^{1}$

Most importantly, the character of Hiro allows the show to create an 'inter-textual link' with Nissan, both simplistically and on a deeper level. The virtues and special features of the Versa are

\footnotetext{
${ }^{1}$ Producer Greg Beeman mentioned that they had wanted a right-handed car for the character Elle Bishop (Kristen Bell) to drive in scenes set in Ireland; actor Greg Grunberg responded with: 'but Nissan doesn't make one' ('Fight or Flight', 2.5 , commentary track).
} 
discussed by Hiro and his best friend Ando (James Dyson Lee) within the show across several episodes, including its comfort and uniqueness ('One Giant Leap', series one episode three), the ease of finding it within a parking garage ('Hiros', 1.5), and its ability to get through a gun battle without a scratch on it ('Unexpected', 1.16). In the second episode ('Don't Look Back', 1.2), Hiro discovers the $9^{\text {th }}$ Wonders! comic book at a newsstand in New York City, featuring his leap in space and time as the main storyline, as well as what has yet to occur in his story, which he uses as a template for what he'll do next, including renting a particular car for a drive to Las Vegas. In this way, Hiro works as both spokesperson and consumer. If, as previously claimed by one of the series' producers, the multiple platform initiative helped 'lure' (Kushner 2006) viewers into both watching the series and buying its featured products, Hiro thus provides a model for how the viewer should react, or, as Derek Johnson puts it, serves as an example of appropriate fan behaviour (Johnson 2007, 76).

The multiple platforms throughout which the transmedia text of Heroes flows exist not only paratextually in online comics, videos, and interactive games, but within the television series itself. The $9^{\text {th }}$ Wonders! comic book integrates Nissan both online and in the television series. Ando uses the Internet to download web videos of another character (super-strong exotic dancer Niki Sanders (Ali Larter)) onto his iPod - it is the idea of meeting Niki, who lives in Las Vegas, that prompts Ando to travel with Hiro. Thus the product-placed iPod shows its capacity to not only access and transfer content across multiple platforms, but also to connect two disparate individuals within the story and play a role in advancing the plot. ${ }^{2}$ Hiro's actions, whether it's driving to Las Vegas or choosing the type of car he should do it in, are informed by a separate platform that reveals his actions: the comic book. Since the comic book specifies a very particular car - the Nissan Versa Hiro will not accept any substitute.

Hiro: Nissan Versa. Nissan Versa.

Car Rental Clerk: That's a popular choice. Let me check to see if we still have any left. Hiro: Nissan -

Ando: Hiro! [subtitled] We've got a connecting flight leaving for New York.

Hiro: [subtitled] We're not flying.

Ando: [subtitled] Why not?

\footnotetext{
${ }^{2}$ Unfortunately, this is not universally applied within Heroes. The second series also introduced a character, Monica Dawson (Dana Davis), struggling to survive in post-Katrina New Orleans, faced with the loss of both parents and educational opportunities. In her introductory episode, news footage of the aftermath of Katrina plays over her face ('The Kindness of Strangers', 2.4). This seems to be Heroes striving for social relevance within in the narrative; however, the real social relevance is that this character's story never significantly overlapped with any of the others, stranding her in the greater narrative arc much as the residents of New Orleans were stranded in the weeks and months following the devastation (Giroux 2006). It is only when she is brought to New York to have her powers "tested" that she begins to interact with the larger storyline, only to be taken back to New Orleans and given a product-placed iPod ('The Line', 2.6). It's a synergistic placement; Monica's power is "muscle mimicry"; the video iPod has been loaded with videos that will help her develop her amazing skills, thus positioning the iPod as a key tool in making its users amazing as well. Monica uses what she has learned, thanks to the iPod, to attempt to clean up the crime and devastation of New Orleans. Yet, after New Orleans faded from news coverage, Monica's storyline was given less screen time, and after the second series of the show, there have been no reappearances of this character within the terrestrial television story. While the iPod had been used in series one in a way to tie two disparate character stories together, thereby also underscoring the ability of the product to cross international borders, it does not serve the same function within Monica's story.
} 
Hiro: [subtitled] It says we rent a car. [Hiro opens the comic book and shows the panels to Ando.]

Ando: Eh? [subtitled] We drive all the way?

Hiro: [subtitled] Yes. In a Nissan Versa.

Ando: Ah, Hiro, [subtitled] Do you know how long that's going to take? Suppose she doesn't have that exact car?

Car Rental Clerk: You're in luck. We have one left.

Hiro: [subtitled] It's our destiny.

('One Giant Leap', 1.3)

These moments essentially render the Versa as a third character within these scenes. Indeed, it is becoming increasingly common for publications writing about the practice of product placement or integration to refer to the placed products as characters, underscoring the idea that the high level of involvement of said products in the storylines transubstantiate the products into something beyond themselves (see James 2004; Levin 2006; Clifford 2008). This scene in particular highlights the consumption relationship that is expected through the use of placement. As Hiro says, the Nissan Versa is "our destiny," having been told by the comic book.

Hiro's characterization serves as the primary link between viewer, product, and story within Heroes. He is a comic book reader and well-versed in the language of fan and comic culture, which serves as an escape from life as a low-level functionary in the company Yamagato Industries, which allows for no separate identity from the corporate identity; this is later shifted to Hiro's wish to do something besides run a corporation when it is revealed he is the heir of Yamagato Industries. His low-echelon position was a way for his father to teach Hiro responsibility and allow him to mature before taking over the company ('Distractions', 1.14). Further, by explicitly linking Hiro's action with the comic book that Hiro reads, the viewer is, in essence, offered a subtle push toward the transmedia narrative content available on NBC.com. In this way, the series advertises itself by making itself a product placed within itself.

This metatexual narrative promotion extends further. When he first discovers his powers, he tries to convince Ando, over drinks, that he is like Spock ('Genesis', 1.1), tying him in culturally with the original NBC science-fiction series Star Trek (Desilu Productions/Paramount Television, 1966-9), which has a multinational cultural cachet (Davies and Pearson 2007, 209-23). This points to Hiro's and Heroes' aspirations to be afforded the same status. When he is later arrested in New York City on suspicion of murder, he repeats the word 'Spock' to identify himself, and gives the iconic Vulcan sign to the police officers ('Don't Look Back', 1.2); the words 'Spock' and 'Nissan Versa' are the only ones he knows in English at that juncture. When Hiro moves forward in time and space during the first episode and ends up in New York City, his first act is to buy a comic book from a local stand; on the cover is his own arrival in New York, with what will become his catchphrase: 'Yatta!' ('We did it!' in Japanese), and his entire conversation and adventure with Ando in the Japanese bar recapitulated within its pages ('Don't Look Back', 1.2).

The important point regarding Hiro is that he is an identifiable spokesperson for both Nissan and for the show itself. Masi Oka, the computer programmer turned actor (much as Hiro is a programmer 
turned superhero) who plays Hiro, carried the bulk of the initial publicity work for the show, including interviews on talk shows and a cross-promotional appearance on the Aaron Sorkinproduced series Studio 60 on the Sunset Strip (Warner Bros./Show Money Productions, 2006-7), also on NBC ('The Harriet Dinner', 1.13). In interviews Oka carried Hiro's characterization (innocent, geeky, sweet) and Hiro was given a great deal of screen time in the first season.

\section{Multiplatform Branding: Monetizing Fan Engagement}

Nissan's presence is not limited to the television medium. NBC and Nissan were relatively early adopters of providing television episodes for free online. I'll be examining in more depth at the end of this article the implications of online content, but the current model on the NBC website (among others) is quid pro quo; the viewer must watch an ad to get to an episode. This extends to the other multimedia content available on the site. On the Heroes page, they provide online interactive graphic novels (also available in PDF format for downloading); the interactive graphic novels themselves are technologically structured to replicate the DVD viewing experience, such as providing clickable 'Easter eggs' within the file for the savvy viewer-user. They also provided graphic novels as videos in animated format.

Further, in 2008, NBC.com introduced an interactive function known as iStory': 'You are the main character of an evolving interactive story. Meet the characters from Evolutions and the show, shape the rest of the Heroes story, and experience the Heroes universe first-hand!' (quoted in Hickerson 2009). Thus Heroes and Nissan allow the user to share in the Hero(ic) experience in a networkcontrolled context, even as they delineate them by whether they were online characters or television ones. While other genre series within or near the examined period have included metatextual elements that refer to fan practices, particularly fan fiction, ${ }^{4}$ Heroes appropriates and contains such activities within the iStory application, as it does within the $9^{\text {th }}$ Wonders! comic book for Hiro. As part of the marketing strategy NBC employed during the first season, a short spoof video was released to YouTube, called 'Zeroes' as part of a network-wide initiative to use viral videos to extend the brands of shows. None of these contained any reference to NBC or when the related series would air, in order to 'build up credibility' with potential viewers (Adalian 2007). The creator of the video, Vince Manze (NBC's 'promo guru'), thought that audiences knowing it was created by NBC would be a detriment (Adalian 2007). By not identifying its genesis, Manze and NBC were clearly hoping to pass it off as fan-created.

The connection between these elements is evident within the cinematography of the series itself; the show is based on a comic-book palette, with highly saturated colour and each episode title written across some element within a scene, as if it is a comic panel. It is also vertically integrated with the official NBC Heroes page, which provides an interactive comic book that fills in the gaps between episodes or provides additional character development. Yet, each of these online comic books

\footnotetext{
${ }^{3}$ While NBC.com explains that the 'I' in iStory stands for interactive, the combination of a lower case I with another word mirrors that of another Heroes sponsor, Apple. NBC released Apple iPhone applications specifically related to Heroes in 2009 (Libonati 2009).

${ }^{4}$ See 'Superstar' an episode of Buffy the Vampire Slayer (Mutant Enemy Productions/Sandollar Television/Kuzui Entertainment/20th Century Fox Television, 1997-2003; 4.17), which features an alternate universe in which a minor character becomes the star of the show, and 'The Monster at the End of This Book' (4.18), 'Changing Channels' (5.8), 'The Real Ghostbusters' (5.9) and 'The French Mistake' (6.15) from the series Supernatural (Kripke Enterprises/Wonderland Sound and Vision/Warner Bros., 2005- ), all of which operate in an explicitly metatextual context.
} 
features an ad for Nissan as its opening panel; the Nissan is in motion, as people stand to the side, astonished. Nissan thus becomes another superhero, a vehicular, evolutionary ' $9{ }^{\text {th }}$ Wonder'. Nissan is also integrated into the story, following a trend that DC and Marvel comic books initiated in 2006 to integrate product placement within all of their comic book lines (Steinberg 2006). The product placement within Heroes is so prevalent that it merits its own page on the Heroes wiki, listing the numerous instances of product placement that span all four series of the show (Heroes Wiki n.d.). This product and story integration is the way in which Heroes serves both as an advertisement for Nissan, itself, and the network and as transmedia storytelling. In terms of the arc of the series, Heroes has a three-fold multiplatform strategy: the television series, in which episodes generally follow three to four separate storylines per episode; the comic books, which provide one-off or multiple issue arcs following one character; and the webisodes, which often feature characters not seen within the central television narrative. Heroes has followed this pattern fairly closely, tailoring content to the medium in which it is being presented.

For both the graphic novels and the webisodes, serving as transmedia elements of the narrative means that their purpose is to enhance or deepen characterization or story arcs in ways that can enrich the viewer's experience without detracting from the terrestrial series. Heroes' promotional apparatus thus becomes not just about selling but 'advancing and developing' its narrative (Gray 2010, 5). In what Jonathan Gray terms paratexts, the meaning of a series is no longer located solely within the text, but extends across multiple platform and iterations. These paratexts can serve to aid the audience's 'speculative consumption' of the television text (as entryway paratexts) or extend the narrative universe (in media res paratexts) (ibid., 25). Gray argues that these paratexts resuscitate the auteur function within television, thus acting as another marker of quality (Gray 2010, 113). That being said, as Jenkins argues, structuring film or television's narratives with these elements means each should stand and/or be enjoyed on its own terms (Jenkins 2006, 96) as well as enhancing the main narrative. The difficulty in achieving this was made manifest in Jenkins' example of the Matrix trilogy, but it is just as applicable to Heroes. As I will discuss in greater depth below, viewers incapable of or uninterested in following the transmediated elements of Heroes were given the impression that certain arcs or characters were unresolved or abandoned, rather than simply extended on a different platform.

From the network's perspective, however, the types of strategies discussed above seemingly operated primarily to monetize engagement. That is, '[g]enre hybridization, serialized narrative form, and product tie-ins - arose as a means to stimulate the profitable overconsumption of fans' (Johnson 2007, 62). That is, these varied forms of transmediated and interactive storytelling appear to offer interested viewers access to and possibly power over the direction of narrative or character; a proximity that could upset the power binary between producers and viewers. Johnson, however, argues that it also allows industry to manage both fans and conflicts 'with executive and corporate interests' (Johnson 2007, 63). The network-created viral video and the interactive iStory application may thus cultivate involvement with the Heroes' brand, but it is on the network's terms (see Grainge 2007, 29; and Lury 2004, 7); that is, to 'intensify the quality demographics' by 'animating an existing audience via consumer activity' though through transmedia storytelling (Caldwell 2006, 118), perhaps most importantly through the webisodes.

These, however, are just a few examples of how Heroes has worked at 'defining the contours of what the brand can mean', so that 'consumers are free to produce the shared meanings and social relations that the branded good will help create in their life' (Arvidsson 2005, 245). Heroes also 
uses the associative properties of its guest stars to connect itself to particular film and television texts as a way to brand the series as part of that genre. George Takei appears as Hiro's father Kaito in the first series; in a knowing nod, Kaito's license plate on his car was NCC-1701, the registry number for the USS Enterprise in the original series. In the second series, Nichelle Nichols, who played Lieutenant Uhura on Star Trek, joined the cast as Nana Dawson. Taken with Hiro's avowed love of Star Trek (mentioned not only within the show, but numerous references on 'Hiro's blog', an online adjunct that included the use of 'stardates' to date entries), it provides another historical link to the series.

Other guest stars illuminate this brand strategy, although they bring a different cachet with them. Antagonist Daniel Linderman, mentioned often in the first half of the first series but never seen, finally appeared in the episode 'Parasite' (1.18), played by Malcolm McDowell, picked in particular by creator Tim Kring because of the associations McDowell brings after playing role such as the title character in Caligula (Tinto Brass, 1979) and, most famously, Alex DeLarge in A Clockwork Orange (Stanley Kubrick, 1971). Kring's reason was that 'After 17 episodes of building this guy up, we knew we needed an actor with a certain weight [...]. And Malcolm certainly has weight' (Jensen 2007). Casting Christopher Eccleston as Claude, whose power was invisibility, could also be read as an attempt to cash in on a particular cultural icon (The Doctor in Doctor Who (BBC/CBC, 2005- )) enjoying renewed popularity in both the United Kingdom and the United States. This becomes more clear when Claude's first word of dialogue is 'fantastic', a nod to that word's repeated use by Eccleston during his incarnation as the ninth Doctor. As with McDowell and Takei, Eccleston is placed as a product in his own right; all three stand in a marked difference to the regular cast in that they have already been encoded with particular media and cultural meanings that the show appears to use as both character shorthand and a potential lure for new viewers. Together with the (nearly) single-sponsorship of the series by Nissan, this use of the special guest star is yet another example of Heroes' cross-promotional methods ranging from the earliest television tactics to the most recent. They further point to Heroes' positioning as a mainstream cult property, in the ways in which it uses its guest stars as a draw for a very particular kind of viewer.

Heroes, as a product, uses all these transmediated elements to promote itself. It is by no means the first or only show to do so. Yet as a genre show, it is positioned to appeal to technologically adept viewers who can use the same elements that the show takes advantage of to do the promotional heavy lifting. While the term promotional in regards to Internet content will be discussed further below, the technologically enabled viewer, and the implications of that demographic, does fit in with NBC's goals - both old and new. First, NBC has sought and delivered upscale audiences to advertisers. This dates back to Brandon Tartikoff's time as entertainment president at NBC, where he was credited with moving NBC's key demographic from 'Kmart to Saks Fifth Avenue' (Tartikoff and Leerhsen 1993, 12) in the 1980s. As Lotz writes: 'NBC's ability to deliver viewers most highly prized by advertisers was closely tied to its ability to create distinctive programming to take certain content and scheduling risks, and it remained a key determinant of the networks cultural production' (Lotz 2007a, 264). While NBC struggled in the 2004-5 season, Heroes represented an upsurge in both viewing numbers and critical respect, at least for its first series. It also was at the forefront, as discussed throughout this article, of using transmedia elements to attract the affluent viewer-users that would have greater opportunity, due to the cost of equipment and access, to participate. Rather than democratizing television through these alternate platforms, Heroes is still positioned, regardless of the delivery system, to the original demographics NBC sought under Tartikoff. 


\section{Transmedia Storytelling or 'Soulless Cross Promotion'?}

The webisodes, which debuted in the summer of 2008, also replicated the relationship between the text and its advertising context of the terrestrial series. 'Going Postal' was one of the series of webisodes; it was released in three parts of approximately three minutes each chronicling the adventures of postal worker Echo DeMille (Kiko Ellsworth), as he unleashes his powers while being chased by a dog and then is discovered by members of a secret organization that wishes to recruit and study him. The final shot of the first episode features a lingering shot of sponsor Sprint's new touch phone. Each was preceded by an advertisement for Sprint, which mocked the practice of product placement. There is something of a confusion of meaning at work within the webisodes, due to the issues around the writer's strike. One of the main points of contention between the WGA and the Alliance of Motion Pictures and Television Producers (AMPTP) was whether online content constitutes promotional or additional text. 'Going Postal' integrated both a Sprint phone and a Nissan Versa within nine minutes; it also integrated one character from the terrestrial version of the series. They were structured both as a second-shift text as well as promotional material for Sprint, Nissan and the series itself; despite the term integration and what it implies in terms of how the product is placed, each of these products call attention to themselves regardless of the platform. It is a further example of Caldwell's contention that second-shift programming used the same economic and textual models as television, fitted for the new platform (Caldwell 2003). 'Going Postal', among the other webisodes for Heroes ('Destiny', 'The Recruit', 'Hard Knox' and 'Nowhere Man') focused more intently on a single character or a single arc; each episode ranges between three and five minutes - with approximately three to five episodes devoted to character and story. Thus, its length, its status as both a story adjunct and promotional material for the series, and the product integration employed within the text, positions it within a grey area between text and commercial both for the placed products and the series itself. The length of these webisodes is similar to that of a commercial break. They are thus situated to act as both an entryway paratext and an in media res paratext (Gray 2010, 25), in that they can both promote the series and add dimensions to the existing terrestrial television narratives. At this second level, the line between webisodes as promotional material and webisodes as second-shift narratives becomes increasingly blurred.

Further, the writer's strike, which started in November of 2007 and ended in February of 2008, meant that broadcast and cable scripted programs were off the air for four months of the typical nine-month season on American television. While some series rushed available scripts into production at the end of the strike and thereby returned to finish out a shortened season, Heroes, with its reliance on special effects, transmedia components, and CGI, elected to end its season in December with the episodes that had already been filmed.

Heroes did not air webisodes until 2008, but other NBC-produced series, such as Battlestar Galactica (British Sky Broadcasting/David Eick Productions/Universal Media Studios, 2004-9) and The Office: An American Workplace (Reveille Productions/NBC Universal Television/Deedle-Dee Productions, 2005-13) were asked to provide webisodes of their shows in 2006 and 2007. This content, however, was put into place without an agreed-upon economic model, either current or predictive, for what the Internet can provide in terms of value-added or actual revenues, between writers, actors, and studios. Although its transmedia content has potentially raised the profile of Heroes, among other series, this lack of knowledge of the profit potential of the Internet led to a WGA strike that halted the 2007/8 season. As Caldwell argues, the industry's instabilities in terms of rising product costs, the heightened obsolescence of technology, and most importantly for this analysis, labour relations, serve as a larger threat to network economics than even the introduction 
of cable television in the 1970s $(2003,45)$.

Yet, the same tools the networks used to promote these series were thus appropriated by the WGA to mobilize fan communities and garner support among viewers through strike updates, blogging, and posting strike (and fake 'corporate exposure') videos on YouTube. Joss Whedon reached out to his fans, using the fan-created blog Whedonesque.com to update them on the strike's progress as well as taking the media to task for negative portrayals of the striking workers (Anon. 2008). ${ }^{5}$ It was thus not only the studios that were capable of capitalizing on the technologically sophisticated and engaged viewer-user; writers and writer-producers also sought the support of these same viewers. Johnson argues that '[i]nviting the audience into closer relations with the text and its production $[\ldots]$ served the interest and goals of a television industry reorganizing itself around multiplatforming' (Johnson 2007, 68). In this instance, rather than keeping viewers within the branded multiplatform universe of a series, the WGA sought to mobilize these same engaged viewers as an adjunct union, so to speak. That being said, while the strike was resolved on February 12 2008, with agreed-upon concessions on both sides, it is difficult to measure how much of an influence the fans had on the AMPTP, regardless of the WGA's insistence that viewers and fans were necessary. It is more likely that the 'make-goods' and returned investments to advertisers figured more heavily on the strike; that is, they announced that they would demand their money back before mid-December, as the strike means that those who have contracted for first-run programmes were not, in fact, getting what they paid for (Consoli 2007).

Heroes, an expensive show to produce, both in terms of cast size and in special effects and other production costs, finished a shortened second season in December 2007, and did not return to broadcast until the following season. The aforementioned webisodes, produced in corporation with both Nissan and Sprint, were created not only to serve as another element in the expanding narrative transmedia universe, but to 'build anticipation' for the third season (Goetzl 2008), thus attempting to explicitly position them as promotional material. On multiple levels, then, the initiatives and trajectory of the series continued to mirror both the NBC network and the industry as a whole in terms of its struggles with a changing television industry.

\section{Conclusion}

With an unexpected ten-month hiatus between seasons, Heroes' brand identity and transmedia capabilities became vitally important. Yet, despite the resolution of the strike and classification of content such as webisodes as television text, they still served a promotional function for the series and the placed products. John Fiske argues that it is important to differentiate between programme and text; the programme operates as a 'stable entity' to be commodified and sold, while the text itself is open to multiple readings (Fiske 2006, 17). But where do you locate a dispersed text such as Heroes? The programme, the texts, and the advertisements appeared across multiple platforms, which should thus provide multiple entry points for engagement and even potential counter-

\footnotetext{
${ }^{5}$ While it is slightly outside the purview of this discussion, Whedon's writing and eventual release of the web-only limited series Dr. Horrible's Sing-along Blog itself offers an interesting case study of the shifting economics of American television, transmedia, and the issues surrounding the strike and its resolution. Whedon stated that one goal in creating the series was to prove that web content could be profitable outside the network system (Vary 2008). While there is an argument to be made that Dr. Horrible's overwhelming success could be attributable to the strength of the Whedon brand, the debut and relative success of streaming series such as House of Cards or the fourth season of Arrested Development seem to indicate the feared fundamental shift in the definition of television is finally coming to fruition.
} 
readings. Yet for its surface messiness, its disparate flows, it seems clear that the network itself operates as a metaphorical dam that relocates viewer engagement into the area that will provide the most profit. As Caldwell argues, 'The question of audience can no longer be isolated from the issue of television's industrial base, since television now creates and sanctions specific rituals for viewers, ones inextricably tied to new video production and home entertainment technologies" (Caldwell 1995, 203; italics in original); said rituals, since they are 'creat[ed] and sanction[ed]' by the industry, have thusly been used to objectify and market to these particular audience members.

Kompare argues that examinations of the technology of, around, and about television tend to be marginalized in analysis because television's main purpose has been to sell audiences to advertisers, rather than selling products to viewers $(2006,337)$. Yet, at the most basic level, the reason television has sold audiences to advertisers is to support programming; for the advertisers, they most certainly wish to sell products to viewers. The convergence of producers and viewers, of media and technology, provides new venues in which to do both. Heroes, and NBC itself, have at certain points, successfully made use of these new venues and, in many ways, contained and professionalized (Cubitt 1991, 18) these platforms to extend their properties on their terms. In this way, they can address the viewer with the series and products featured therein at nearly every point of entry. The transmediated narrative structure of Heroes, despite offering a different (and potentially more viewer-engaged) method of television storytelling, nevertheless replicated the same programming and advertising relationship that has existed since American television's inception.

\section{References}

Adalian, J. (2007) 'Subtlety Succeeds as NBC Spreads Buzz: “Zeroes” Takes in 1.5 Million Viewers Online', Variety, 8 March. Accessible at http://www.variety.com/article/VR1117960789.html?categoryid=14\&cs=1. Accessed 29 September 2013

Anonymous (2008), 'More Joss Strike Talk', Whedonesque.com. Accessible at http://whedonesque.com/comments/14650. Accessed 29 September 2013

Atkinson, C. (2007a) 'Upfront Traders Wrestle with the Digital Dialogue', Advertising Age, 26 February, 78(9), 3 and 41

--- (2007b) 'Is Crucial Daypart Finally Past its Prime?', Advertising Age, 10 May, 78(20), S1-S2

Arvidsson, A. (2006) Brands: Meaning and Value in Media Culture, London: Routledge

Avery, R. J. and Ferraro, R. (2000) 'Verisimilitude or Advertising? Brand Appearances on Prime Time Television', The Journal of Consumer Affairs, 24(2), 217-244

Caldwell, J. T. (1995) Televisuality: Style, Crisis, and Authority in American Television, New Brunswick, NJ: Rutgers University Press

--- (2003) 'Second Shift Media Aesthetics: Programming, Interactivity, and User Flows' In: J. T. Caldwell and A. Everett (eds). New Media: Theories and Practices of Digitextuality. London: Routledge, pp. 127-144 
--- (2004) 'Convergence Television: Aggregating Form and Repurposing Content in the Culture of Conglomeration', in L. Spigel and J. Olssen (eds), Television After TV: Essays on a Medium in Transition, Durham, NC: Duke University Press, pp. 41-74

--- (2006) 'Critical Industrial Practice: Branding, Repurposing, and the Migratory Patterns of Industrial Texts', Television and New Media, 7(2), 99-134

Clifford, S. (2008) 'Product Placements Acquire a Life of Their Own on Shows', New York Times, 14 July. Accessible at

http://www.nytimes.com/2008/07/14/business/media/14adco.html? r=1\&fta=y. Accessed 29

September 2013

Consoli, J. (2007) 'Strike has Cash-back Clock Ticking', Mediaweek, 19 November. Accessible at http://www.mediaweek.com/mw/news/recent display.jsp?vnu content id=1003674078. Accessed 29 September 2013

Cubitt, S. (1991) Timeshift: On Video Culture, London: Routledge

Davies, M. M. and Pearson, R. (2007) 'The Little Program That Could: The Relationship Between NBC and Star Trek', in M. Hilmes (ed.), NBC: America's Network, Berkeley: University of California Press, pp. 209-223

Donaton, S. (2005) 'The Marketing Revolution will be Televised, Online and On Demand', Advertising Age 76(11), 14 March, 26

Fiske, J. (2006) Television Culture, London: Routledge

Giroux, H. (2006) Stormy Weather: Katrina and the Politics of Disposability, Boulder, Colo: Paradigm Publishers

Goetzl, D. (2008) 'Nissan, Sprint Sponsor “Heroes” Web Series', Media Daily News, 11 July. Accessible at

http://www.mediapost.com/publications/index.cfm?fa=Articles.showArticle\&art_aid=86381.

Accessed 29 September 2013

Grainge, P. (2007) Brand Hollywood: Selling Entertainment in a Global Media Culture London:

Routledge

Gray, J. (2010) Show Sold Separately: Promos, Spoilers, and Other Media Paratexts, New York: New York University Press

Heroes Wiki (n.d.) 'Product Placement'. Accessible at http://Heroeswiki.com/Product placement. Accessed 29 September 2013

Hickerson, M. (2009) 'New Interactive "Heroes" Story Goes On-Line', Slice of SciFi, 11 February. Accessible at http://www.sliceofscifi.com/2009/02/11/new-interactive-heroes-story-goes-on-line/. Accessed 25 March 2014

Hills, M. (2010) 'Mainstream Cult', in S. Abbott (ed.), The Cult TV Book: From Star Trek to Dexter, New Approaches to TV Outside the Box, Berkeley, California: Soft Skull Press, pp. 67-73

James, M. (2004) 'Products Are Stars in New Ad Strategy', LATimes.com, 2 December. Accessible at http://articles.latimes.com/2004/dec/02/business/fi-trump2. Accessed 29 September 2013

Jenkins, H. (2006) Convergence Culture: Where Old and New Media Collide, New York: New York University Press

--- (1992) Textual Poachers: Television Fans and Participatory Culture, London; Routledge Jensen, J. (2007) 'Nobody’s Hero', Entertainment Weekly, 16 March. Accessible at 
http://www.ew.com/ew/article/0,20014468,00.html. Accessed 29 September 2013

Johnson, D. (2007) 'Inviting Audiences In: The Spatial Reorganization of Production and Consumption in "TVIII", New Review of Film and Television Studies, 5(1), 61-80

Kompare, D. (2006) 'Publishing Flow: DVD Box Sets and the Reconception of Television', Television and New Media, 7(4), 335-360

Kushner, D. (2008) 'Rebel Alliance: How a Small Band of Sci-Fi Geeks is Leading Hollywood into a New Era', Fast Company, 11 April. Available from:

http://www.fastcompany.com/magazine/125/rebel-alliance.html. Accessed 29 September 2013

Lafayette, J. (2006) 'Nissan in Multimedia Heroes Deal: Theater, iTunes Components Included in

Push for new NBC Show', TV Week, 28 July. Accessible at

http://www.tvweek.com/news/2006/07/nissan in multimedia heroes de.php. Accessed 29

September 2013

Learmonth, M. (2007) 'Nets Face Muddled Metrics: Upfronts Unsettled by Ad Agony' Variety, 2-8 April, 18-21

--- (2008) 'Distributors, Networks Push for More Ads in TV Shows Online', Advertising Age, 6 October, 79(37), 3 and 41

Levin, G. (2006) 'The Newest Characters on TV Shows: Product Plugs' USA Today, 20 September. Accessible at http://usatoday30.usatoday.com/life/television/news/2006-09-19-productintegration x.htm?csp=26. Accessed 25 March 2014

Libonati, J. (2009) 'NBC.com's Mobile Initiatives Post Explosive Growth: Mobile Full Episodes and Smart Phone Sites Led Record Traffic', NBC.com, 28 January. Accessible at http://www.nbcumv.com/entertainment/release_detail.nbc/entertainment-20090128000000nbc46com039sm.html. Accessed 29 September 2013

Lotz, A. (2007a) 'Must-See TV: NBC's Dominant Decade', in M. Hilmes (ed.), NBC: America's Network, Berkeley: University of California Press, pp. 261-274

--- (2007) The Television Will Be Revolutionized, New York: New York University Press

Lury, C. (2004) Brands: The Logos of the Global Economy, London: Routledge

McClellan, S. (2003) 'Will TiVo Kill Telelvision, or Are Viewers Too Lazy to Zap?', Broadcasting and Cable, 29 September, 19

Pearson, R. (2010) 'Observations on Cult Television', in S. Abbott (ed.), The Cult TV Book: From

Star Trek to Dexter, New Approaches to TV Outside the Box, Berkeley, California: Soft Skull Press, pp. 7-17

Sandler, K. S. (2007) 'Life Without Friends: NBC's Programming Strategies in an Age of Media Clutter, Media Conglomeration, and TiVo', in M. Hilmes (ed.) NBC: America's Network, Berkley: University of California Press, pp. 291-307

Steinberg, B. (2006) 'Look - Up in the Sky! Product Placement!', Wall Street Journal Online, 18 April. Accessible at http://online.wsj.com/public/article/SB114532350031828284-

2nRn41Kln8fZjCEf0UgX0U1Pqy4_20060425.html. Accessed 29 September 2013

Tartikoff, B, and Leerhsen C. (1993) The Last Great Ride, New York: Dell Publishing

Thompson, S. (2004) 'New Reality: Consumers are in Control: Issue Joins Accountability as Key Challenge for Marketers', Advertising Age, 11 October, 75(41), 1 and 51

Vary, A. B. (2008) 'Dr. Horrible’s Sing-Along Blog: An Oral History', Entertainment Weekly, 25 
July. Accessible at http://www.ew.com/ew/article/0,20213067_20213068_20214910,00.html. Accessed 29 December 2013

Wallington, A. (2008) Heroes: Saving Charlie: A Novel. New York: Del Rey Books

Winslow, G. (2007) 'Cross-Platform Deals Change Sales, Upfront: Trend Highlights Changes in Consumer Behavior, Delivery Options', Broadcasting and Cable, 7 May, 3A and 9A 